\title{
Chemical monitoring of baru (dipteryx alata vog.) pulp fermented beverage
}

\author{
Jéssyca Santos SILVA ${ }^{1}$, Nathalya Bastos Soares FERREIRA², Eduardo Ramirez ASQUIERI ${ }^{2}$, Clarissa DAMIANI²* (D), \\ Elaine Meire de Assis Ramirez ASQUIERI ${ }^{2}$
}

\begin{abstract}
Considering that the consumption of baru is not yet fully diffused among humans, it is possible to perceive the need for its greater use, mainly because it is a natural source of sugars, essential raw material for the production of various products, such as beverages fermented. In view of the above, the objective of this work was to develop fermented alcoholic beverage from the pulp of baru, chemically monitoring the fermentation and aging process. Throughout the processing, the fermented presented behavior as expected, as a decrease of sugars ensuring an effective fermentation without interferents, as high amounts of acetic acid and propagation of deteriorating organisms. With this, it was possible to develop and chemically accompany the alcoholic beverage from pulp of baru, obtaining results that met the brazilian legislation in force for fruit fermented, providing a new source of exploitation of this raw material little explored.
\end{abstract}

Keywords: Dipteryx Alata Vog; cerrado fruit; fruit wine; fermentation.

Practical Application: Baru pulp can be used as an alternative to produce a quality fermented alcoholic beverage.

\section{Introduction}

The Baru (Dipteryx alata Vog.) tree, from the Leguminosae family, disseminated mainly in the brazilian cerrado, is part of the group of native species used by the regional population as a source of family income (Sano et al., 2004). It is one of the most promising species for cultivation due to its multiple uses, including food, timber, medicinal, industrial, landscape and recovery of degraded areas.

As described by Sano et al. (1999), the fruit presents, on average, $12 \mathrm{~m}$ of height by $8 \mathrm{~m}$ of crown diameter. Each tree can produce from 1000 to 3000 fruits whose largest diameter is from 5 to $7 \mathrm{~cm}$ and the smallest diameter from 3 to $5 \mathrm{~cm}$, weighing between 26 to $40 \mathrm{~g}$ and encloses a single seed of approximately $1.17 \mathrm{~g}$. The bark and the pulp are brownish in color and the seed, from cream to white, is surrounded by a dark brown film.

The pulp had a soft, thick, sweet and tender astringent (Rocha \& Santiago, 2009) composition, mainly composed of starch (38\%), total fibers $(29.5 \%)$ and $28.2 \%$, total sugars (20.4\%), proteins (5.59\%), lipids (3.4\%), ashes (2.99\%) and rich in vitamins and minerals such as potassium, copper, iron, calcium, phosphorus, and magnesium, in addition to the tannins $(3112.0 \mathrm{mg} / 100 \mathrm{~g})$ (Valillo et al., 1990; Togashi \& Scarbieri, 1994).

Even with high nutritional value, baru pulp is little used in human consumption and its use is commonly used in cattle feeding for complementation in periods of drought (Sano et al., 2004). Considering that the consumption of this fruit is not yet fully diffused among humans, it is possible to perceive the need for its greater use, mainly because it is a natural source of sugars, essential raw material for the production of various products, such as beverages fermented.
In view of the above, the objective of this work was to develop fermented alcoholic beverage from the pulp of baru, chemically monitoring the fermentation and aging process.

\section{Materials and methods}

The present work was carried out in the Laboratory of Chemistry and Biochemistry of Food, Faculty of Pharmacy, Federal University of Goiás - Brazil. The baru (Dipteryx alata Vog.) pulp was obtained from the sellers of the nut of this fruit, in the local market of Goiânia - Brazil, during the months of september and october of 2011. The pulp was sent directly to the laboratory in the shortest time possible and packaged in a freezer in low density polyethylene bags for further processing. The raw material was characterized by moisture, ash, lipids, proteins, total carbohydrates, energy, soluble solids content, reducing sugars and tannins. All analyzes were performed with three replicates.

\subsection{Elaboration of alcoholic fermented}

The alcoholic fermentation of baru was carried out, in duplicate, with three replications, based on adaptations of Asquieri et al. (2004a) and Vogt (1972).

\section{Preparation of the must}

The must was prepared with water and pulp of baru, chaptalizado and sulphited in small portions, standardized in $24^{\circ}$ Brix, until filling of two distinct tanks of stainless steel, forming two batches. In the latter portion, yeast Saccharomyces cerevisiae, obtained on the local market, was added. 


\section{Vigorous fermentation}

Vigorous fermentation occurred up to the time the must reached the desired soluble solids content. For this purpose, the whole process was monitored for five days in relation to temperature, soluble solids content, $\mathrm{pH}$ and titratable total acidity.

\section{Transfer}

With the end of the vigorous fermentation, the must was transferred to gallons of high density polyethylene (HDPE). Sulphate was added by adding sodium metabisulfite and an anaerobic system was created to prevent contact with oxygen, avoiding undesirable triviality.

\section{Slow fermentation}

The slow fermentation was followed and monitored for ninety days, and every thirty days were carried out the transfers, which consisted of transferring the liquid to another gallon, neglecting the sludge that formed the bottom of the container.

In each transfer, the following analyzes were carried out: soluble solids, reducing sugars, sucrose, total sugars, $\mathrm{pH}$, total titratable acidity, volatile acidity, alcoholic strength, density, free and total sulfur dioxide, phenolic compounds and tannins, with evaluations performed at 30,60 and 90 days.

\section{Packaging and aging}

After the ninety days of slow fermentation, the alcoholic fermentation went through the clarification process with bentonite for twenty-four hours, to then vacuum filtration with celite and kieselguhr.

The filtrate was filled into sterile $750 \mathrm{~mL}$ clear glass bottles, sealed with aluminum stoppers and stored for a period of 6 months at $15{ }^{\circ} \mathrm{C}$ for the aging of the beverage. During this period, also called maturation, two-month follow-up analyzes (2, 4 and 6 months) were performed, including the same ones performed during slow fermentation.

\subsection{Methodology of the analyzes}

\section{Centesimal composition and total energy value}

Moisture: gravimetric method, determined by heating the sample at $105^{\circ} \mathrm{C}$, in greenhouse, until the mass stabilization (Association of Official Analytical Chemists, 2010); Ashes: gravimetric method, in which the material was submitted to the temperature of $550{ }^{\circ} \mathrm{C}$, in muffle, for loss of mass to constant weight (Association of Official Analytical Chemists, 2010); Lipids: method based on the mixture of three solvents: chloroform-methanol-water, according to Bligh \& Dyer (1959); Proteins: microKjeldahl methodology (Association of Official Analytical Chemists, 2010), based on the $\mathrm{N}_{2}$ transformation of the ammonium sulphate sample by digestion with sulfuric acid p.a. $\left(\mathrm{H}_{2} \mathrm{SO}_{4}\right)$ and distillation with ammonia release, followed by titration with hydrochloric acid solution. The result is given in $\% \mathrm{~N}$, which will be multiplied by the conversion factor of the nitrogen/protein ratio; Total carbohydrates: estimated by difference, subtracting from 100 the values obtained for moisture, proteins, lipids and ashes; The total energy value was estimated considering Atwater conversion factors of $4 \mathrm{cal} / \mathrm{g}$ for protein and carbohydrate, and $9 \mathrm{cal} / \mathrm{g}$ for lipids (Merril \& Watt, 1973).

Total soluble solids, $\mathrm{pH}$ and titratable total acidity

Soluble total solids: refratometric method, with ${ }^{\circ}$ Brix (Association of Official Analytical Chemists, 2010), using bench refractometer of the brand Shimadzu Milton Roy Company; $\mathrm{pH}$ : portable digital potentiometer of the Micronal brand (Association of Official Analytical Chemists, 2010); Titratable total acidity: titrations with $0.1 \mathrm{~N}$ sodium hydroxide $(\mathrm{NaOH})$, using phenolphthalein as indicator.

\section{Reducing sugars, sucrose and total sugars}

Reducing sugars: The 3,5-dinitrosalicylic acid (ADNS) method, which consists of reducing the ADNS in 3-amino-5nitrosalicylic acid, in the presence of heat, producing different color intensities ranging from light yellow to dark brown (Miller, 1959); Sucrose: difference between the amount of hydrolysed sugars and reducing sugars, multiplied by 0.95 , according to Miller (1959), adapted by Silva et al. (2003); Total sugars: sum of reducing sugars with sucrose, method of Miller (1959), adapted by Silva et al. (2003).

\section{Tannin compounds and total phenolic compounds}

Tannins: spectrophotometric method, using Folin-Denis reagent (Carvalho et al., 1990); Total phenolics: procedure proposed by Swain \& Hillis (1959), using Folin-Ciocalteau reagent and sodium carbonate, with standard curve of gallic acid.

\section{Temperature, volatile acidity, alcoholic strength and density}

Temperature: calibrated using a mercury thermometer; Volatile acidity: water vapor drag and titration with $0.1 \mathrm{~N} \mathrm{NaOH}$ with meq/L result (Association of Official Analytical Chemists, 2010); Alcohol content: determined using the Gay-Lussac alcoholometer, placed directly in the volume of $250 \mathrm{~mL}$ distilled at $20^{\circ} \mathrm{C}$ (Brasil, 2005); Density: picnometric method, according to Brasil (2005).

\section{Free and total sulfur dioxide}

Based on the release of free sulfur dioxide in the presence of sulfuric acid, titrating it with iodine solution. To determine total sulfur dioxide, a strong base was used, then acidified and titrated with iodine solution (Amerine \& Ough, 1976).

\subsection{Statistical analysis}

For the chemical composition of the pulp of baru was used the calculation of the mean, the standard deviation and the coefficient of variation. The data obtained from the chemical monitoring of the baru pulp fermented were analyzed by the analysis of variance, and the variables that proved to be significant $(\mathrm{p}<0.05)$ were submitted to linear regression by the software Sisvar Version 5.3. 


\section{Results and discussion}

The chemical characterization of the baru pulp was crucial because it was possible to trace the nutrient profile of the alcoholic fermentation, as well as how to prepare the must to obtain a better quality product. The results obtained are expressed in Table 1.

The pulp of baru presented results close to those found in the literature, regarding the moisture content of (21.05\%), according to Rocha \& Santiago (2009), ash (3.70\%), by Ribeiro et al. (2011), low lipid content $(3.73 \%)$ and protein $(4.17 \%)$, observed by Alves et al. (2010), both for baru pulp. In this case, the low amount of protein is a positive point, because they are turbidity-causing compounds in the fermented product, which often cause non-crystalline precipitates in white wines, impairing visual acceptability (Ough, 1996).

Table 1. Chemical characterization of baru pulp (wet basis).

\begin{tabular}{cr}
\hline Parameter & \multicolumn{1}{c}{ Mean } \\
\hline Moisture (\%) & $19.30 \pm 0.28(0.01)$ \\
Ashes (\%) & $3.54 \pm 0.04(0.01)$ \\
Lipids (\%) & $3.00 \pm 0.10(0.03)$ \\
Proteins (\%) & $6.72 \pm 0.13(0.02)$ \\
Total Carbohydrates (\%) & $67.44 \pm 0.22(0.00)$ \\
Total energy value $(\mathrm{kcal})$ & $323.67 \pm 0.47(0.00)$ \\
Soluble solids content $\left({ }^{\circ} \mathrm{Brix}\right)$ & $29.87 \pm 0.12(0.00)$ \\
Reducing sugars $(\%)$ & $24.17 \pm 0.15(0.01)$ \\
Tannins $(\mathrm{mg} / 100 \mathrm{~g})$ & $531.00 \pm 3.61(0.01)$
\end{tabular}

Mean values \pm standard deviation and coefficient of variation.
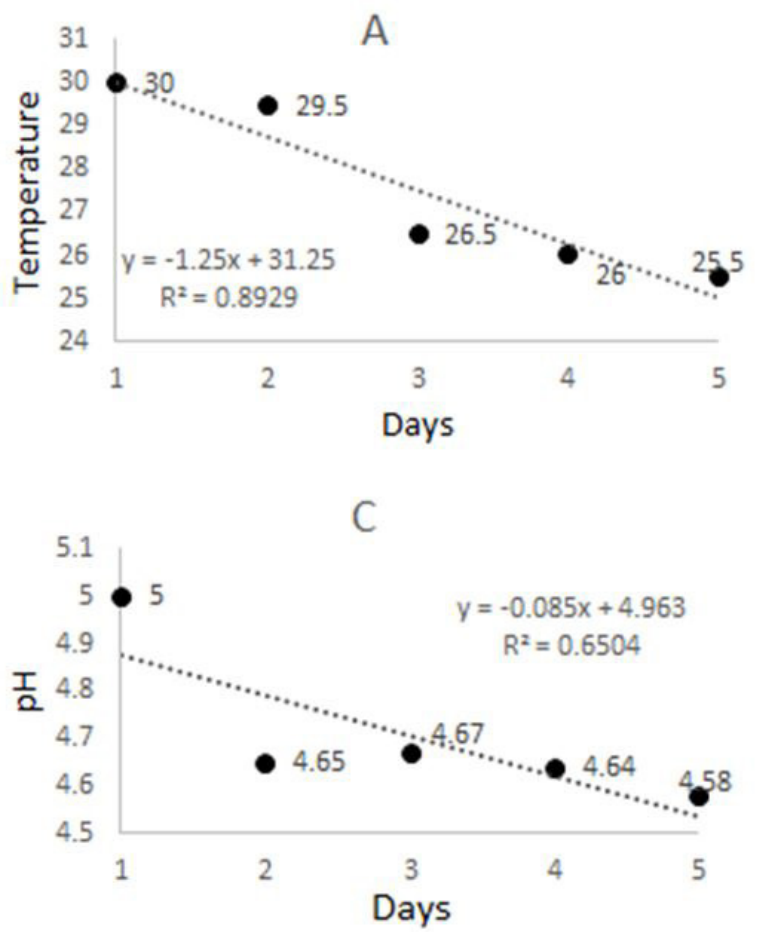

The total amount of carbohydrates calculated was similar to that of Lima et al. (2010) (64.10\%) with the same raw material, as well as the total energy value of the same author $(312.05 \mathrm{kcal})$. In the study by Lima et al. (2010) has shown the high amount of carbohydrates, a large part composed of total dietary fiber and total sugars, and the high energy value suggests to use it as a source of use to promote its consumption.

The content of soluble solids was relatively high, but its content provides an approximate measure of the amount of soluble sugars contained in a sample and the potential alcoholic content that the beverage can reach, and thus the production of fermented beverage is favorable.

In relation to the reducing sugar contents, the value obtained in this work was close to that found by Ribeiro et al. (2011) (29.6\%), in baru pulp. High values for reducing sugars indicate that the baru pulp is potential raw material for fermentative processes.

As for tannins, the value found lower than that found by Alves et al. (2010), (600 mg/100 g), which evaluated the composition and chemical and nutritional characterization of baru. However, the amount of tannins depends on the maturation of the fruit, because the larger the maturation stage, the lower the amount of this substance (Lima et al., 2010).

With the chemical characterization, it can be verified that the baru pulp is excellent fermenting raw material, having factors that contribute to the elaboration of an alcoholic fermentation.

During vigorous fermentation, the must showed a significant behavior of all variables studied in the time factor, and is illustrated in Figure 1.
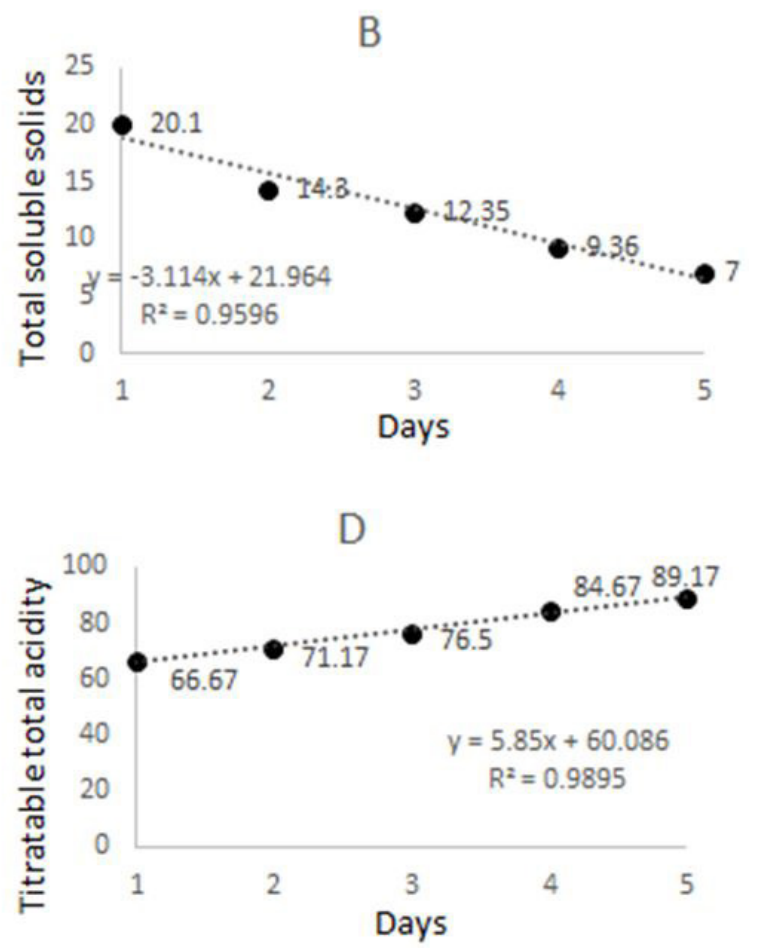

Figure 1. Behavior of the chemical characteristics of alcoholic fermentation of baru pulp (Dipteryx alata Vog.) During the five days of vigorous fermentation. (A) Temperature, (B) Soluble solids, (C) pH and (D) titratable total acidity. 
It was observed that, on the first day of vigorous fermentation, the temperature was the highest $\left(30^{\circ} \mathrm{C}\right)$, due to the high initial sugar consumption by the yeasts, decreasing, from then on, and slowing down the fermentation process. In the fermentation process using the residual syrup of osmotic pineapple dehydration, temperatures at this stage ranged from $31^{\circ} \mathrm{C}$ to $27^{\circ} \mathrm{C}$ (Almada et al., 2009). At temperatures above $35^{\circ} \mathrm{C}$, yeast activity may be inhibited, causing undesirable bacteria to appear (Asquieri et al., 2004b), a fact not observed in the vigorous fermentation of baru pulp.

The soluble solids content decreased during the vigorous fermentation, same behavior found for the pineapple fermented, which decreased from 21 to $9^{\circ}$ Brix on eight days of fermentation (Almada et al., 2009).

The decrease in the soluble solids content during the five days of fermentation indicated a rapid consumption of sugars, since at this stage there is a great detachment of carbon dioxide, a sugar unfolding, which starts slowly and gradually increases in intensity (Rizzon \& Miele, 2002). The considerable decrease of soluble solids indicated that the conversion of sugar to alcohol occurred, as well as in the fermented studies of ata, ciriguela and mangaba (Muniz et al., 2002), whose soluble solids content at the end of this stage was between 5.0 and $6.5^{\circ}$ Brix.

The behavior of $\mathrm{pH}$ and total titratable acidity were inversely proportional, since as the $\mathrm{pH}$ decreased during vigorous fermentation, the total acidity increased. The results obtained in this study were similar to the $\mathrm{pH}$ values at the end of the fermentation, for fermented jabuticaba (3.3) (Asquieri et al., 2004b), fermented banana (3.95) (Arruda et al., 2007) and fermented ata (4.19) (Muniz et al., 2002). In a study carried out, during winemaking of Cabernet Suavignon grapes, the $\mathrm{pH}$ decreased during alcoholic fermentation (Daudt \& Fogaça, 2008).

In the fermentation process, $\mathrm{pH}$ levels tend to decrease, which indicates that hydrogen ion formation may be associated with yeast activity (Starzack et al., 1994). Therefore, the $\mathrm{pH}$ of the fermented beans is a factor that influences the stability of the beverage, and values close to 4.00 favor the growth of the yeast, besides influencing the bentonite activity, used to clarify the fermentation (Boulton et al., 1995).

After the transfer, the fermented must remain in another container for a period of at least 30 days to comply with the slow fermentation phase, also known as malolactic fermentation, in which the malic acid is converted into lactic acid. In addition, secondary reactions occur, such as the release of carbon dioxide and small elevation of volatile acidity. The bacteria of the malolactic fermentation, also, aim to ferment the residual sugar that, still, was not metabolized. In the slow phase, there is again the decantation of solid substances and the contact of the beverage with these substances can cause different problems, being necessary the frequent realization of transfers. In this period, the fermented cannot come into contact with air to prevent oxidation.

During the slow fermentation (Figure 2), soluble solids content (11.21 $\left.{ }^{\circ} \mathrm{Brix}\right)$, reducing sugars (1.74\%), $\mathrm{pH}$ (4.46), alcoholic content $\left(11.33^{\circ} \mathrm{GL}\right)$ and total phenolics $(48.51 \mathrm{mg} / 100 \mathrm{~mL})$ were not influenced by time ( $\mathrm{p}>0.05)$.

The soluble solids content was higher than that of the fermented orange ( $8.0^{\circ}$ Brix) (Corazza et al., 2001), and the amount of reducing sugars was high when compared to the fermentation ata $(0.19 \%)$ and fermented banana $(0.32 \%)$ (Muniz et al., 2002; Arruda et al., 2007). This difference is justified because at the beginning of the slow fermentation there was a new chaptalization, increasing the levels of sugars and soluble solids of the baru pulp must.

As for the $\mathrm{pH}$ index, similar values were found for fermented banana (4.60) (Arruda et al., 2007) and fermented ata (4.13) (Muniz et al., 2002). Acid pH values are justified, because in the malolactic phase of the fermentation, there is formation of lactic acid, leading to the decrease of this variable.

In relation to the alcohol content, studies with alcoholic fruit fermented had similar values, for the fermented ciriguela $\left(10^{\circ} \mathrm{GL}\right)$ (Muniz et al., 2002), cashew (11.5' GL) and orange $\left(10.6^{\circ} \mathrm{GL}\right)$ (Corazza et al., 2001; Torres et al., 2006).

Phenolic compounds are divided into non-flavonoids and flavonoids, and flavonoids include other constituents, among them polyphenols such as anthocyanins, catechins, flavones and flavones, with antioxidant and anti-inflammatory properties (Bermúdez-Sotto \& Tomás-Barberán, 2004). The malolactic fermentation did not influence the amount of phenolic compounds from the fermented of baru pulp, with values close to $500 \mathrm{mg} / \mathrm{L}$.

Figure 2 shows the behavior of the chemical variables that were influenced by the slow fermentation time $(\mathrm{p}<0.05)$.

Sucrose, as well as total sugars, had an increasing behavior during slow fermentation, which was fermented almost entirely and transformed into alcohol, but in the first transfer, in order to reactivate the yeasts to increase the alcoholic content, with a new chaptalization, justifying the increase in the content of sucrose and total sugars. In the fermented cajá (Dias et al., 2003), no sucrose and total sugars were detected at this stage. In the case of the fermented ata (Muniz et al., 2002) and banana (Arruda et al., 2007), total sugars were found to be $0.41 \%$ and $0.42 \%$, respectively, much lower when compared to the fermented of baru pulp.

The titratable total acidity of baru pulp fermentation, even with deacidification with sodium carbonate, occurred at this stage in the first month, showed a significant increase, possibly justified by the formation of lactic acid. This behavior resembled fermented mango (74 meq/L), and fermented pineapple (87.09 meq/L) (Muniz et al., 2002; Almada et al., 2009).

The volatile acidity showed increasing behavior during slow fermentation, due to the possible presence of acetic acid, butyric acid, among others. A high volatile acidity value above $20.0 \mathrm{meq} / \mathrm{L}$ may indicate the presence of spoilage organisms that may eventually convert "wine" into "vinegar" (Amerine \& Ough, 1976). The value found for this variable was higher than that of the fermented pineapple syrup, $(4.03 \mathrm{meq} / \mathrm{L})$ (Oliveira et al., 2012) and inferior to the fermented umbu (7.07 meq/L) (Paula et al., 2012).

The density at $20^{\circ} \mathrm{C}$ is a consequence of the alcohol content and the amount of residual sugar. For the fermented of baru pulp, there was a decreasing behavior of this variable, because at each transfer a quantity of precipitate was withdrawn, causing it to decrease the density gradually. In the study of jackfruit fermentation, the observed density was higher than that found in this study (1.03 mg/L) (Asquieri et al., 2009). 

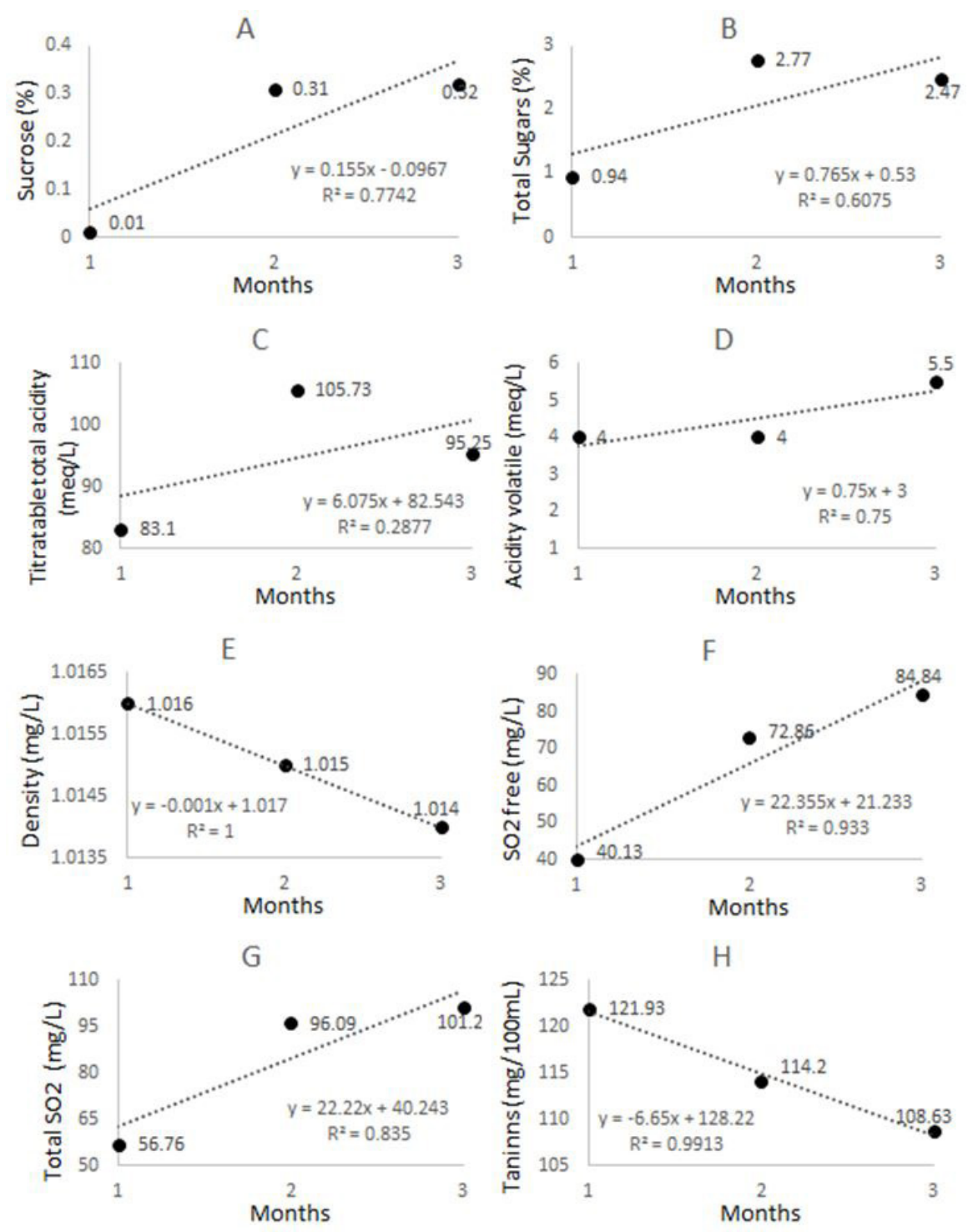

Figure 2. Behavior of the chemical characteristics of the alcoholic fermentation of baru pulp (Dipteryx alata Vog.) During three months of slow fermentation. (A) Sucrose, (B) Total sugars, (C) Titratable total acidity, (D) Volatile acidity, (E) Density, (F) Free sulfur dioxide, (G) Total sulfur dioxide and (H) Tannins. S02 - Sulphurous anhydrous.

Sulphate of the must consists of the addition of gaseous sulfur dioxide in the form of aqueous sodium metabisulfite solution. This process aims to activate alcoholic fermentation, block the action of bacteria and prevent the oxidation of must (Curvelo-Garcia, 2005).

During the slow fermentation, the amount of total and free sulfur dioxide was increased, because at each transfer the fermentation was sulfided to prevent contact with oxygen influencing the quality of the beverage. For the fermented kiwi, the value of free sulfur dioxide was similar $(82.13 \mathrm{mg} / \mathrm{L}$ ) (Paz et al., 2007), but for the fermented jabuticaba the value was lower (around $50 \mathrm{mg} / \mathrm{L}$ ) for total sulfur dioxide (Silva et al., 2008).

Tannins are astringent phenolic compounds that give body to wine. In this work, this compound decreased according to the slow fermentation time because it was precipitated, along with gums and other compounds which, during the transfer, is discarded. $400 \mathrm{mg} / 100 \mathrm{~mL}$ of tannin (Asquieri et al., 2004b) was found in fermented jabuticaba, a higher value when compared to that obtained in this study, approximately $108.63 \mathrm{mg} / 100 \mathrm{~mL}$ at the end of the process, whereas for fermented banana was even lower, $14 \mathrm{mg} / 100 \mathrm{Ml}$ (Arruda et al., 2007).

The aim of aging is to decrease the astringency and herbaceous flavor, if any, of the final product. During aging, the variables soluble solids content $\left(11.22^{\circ} \mathrm{Brix}\right)$, titratable total acidity (91.34 meq/L), volatile acidity ( $5.55 \mathrm{meq} / \mathrm{L})$, alcoholic content $\left(11.50^{\circ} \mathrm{GL}\right)$, density $(1.015 \mathrm{mg} / \mathrm{L})$, total phenolic compounds $(34.90 \mathrm{mg} / 100 \mathrm{~mL})$ and tannins $(81.64 \mathrm{mg} / 100 \mathrm{~mL})$ were not influenced by the storage time factor $(\mathrm{p}>0.05)$.

In a study by Asquieri et al. (2008), who verified the accompaniment, during 11 months of aging, of the alcoholic fermented jackfruit, similar values were observed for soluble solids $\left(12.00^{\circ} \mathrm{Brix}\right)$, titratable total acidity $(100.00 \mathrm{meq} / \mathrm{L})$ and volatile acidity $(6.00 \mathrm{meq} / \mathrm{L})$, but higher values for alcoholic content $\left(13.00^{\circ} \mathrm{GL}\right)$ and density $(1.03 \mathrm{mg} / \mathrm{L})$, and absence of tannins. 
According to the current legislation (Brasil, 1988), shown in Table 2, for fermented fruit, titratable total acidity values between $50 \mathrm{meq} / \mathrm{L}$ and $130 \mathrm{meq} / \mathrm{L}$ are allowed; of volatile acidity of at most $20.0 \mathrm{meq} / \mathrm{L}$ and of alcoholic content between 4.0 and $14.0 \% \mathrm{v} / \mathrm{v}$. Therefore, the alcoholic pulp fermented from baru meets the current brazilian legislation, in these questions.

The reduction of the total phenolic compounds can occur after the packaging, due to the concentration of phenols of high degree of polymerization that may be present in the extract, and these can associate with the cell wall of the yeasts and then be eliminated in the process of clarification and filtration

Table 2. Comparison of the determinants of the legislation for baru pulp fermented at the end of six months of aging.

\begin{tabular}{ccc}
\hline Parameter & Legislation $^{*}$ & Fermented \\
\hline Alcohol content & 4.0 to $14.0 \%$ & $11.50 \%$ \\
Total acidity & 50 to $130 \mathrm{meq} / \mathrm{L}$ & $91.34 \mathrm{meq} / \mathrm{L}$ \\
Acidity volatile & $<20.0 \mathrm{meq} / \mathrm{L}$ & $5.55 \mathrm{meq} / \mathrm{L}$ \\
Anidro sulfuroso total & $<0.35 \mathrm{~g} / \mathrm{L}$ & $0.024 \mathrm{~g} / \mathrm{L}$ \\
\hline
\end{tabular}

${ }^{*}$ Brasil (1988).
(Renard et al., 2001), which was observed for the alcoholic fermentation of baru when compared to the quantity at the end of the slow fermentation $(50.95 \mathrm{mg} / 100 \mathrm{~mL})$ and one month after the package $(34.01 \mathrm{mg} / 100 \mathrm{~mL})$. The same behavior was observed for the tannin content, decreasing from $108.63 \mathrm{mg} / 100 \mathrm{~mL}$ of the slow fermentation to $81.86 \mathrm{mg} / 100 \mathrm{~mL}$ with one month of packaging.

The reduction of the total phenolic compounds can occur after the packaging, due to the concentration of phenols of high degree of polymerization that may be present in the extract, and these can associate with the cell wall of the yeasts and then be eliminated in the process of clarification and filtration (Renard et al., 2001), which was observed for the alcoholic fermentation baru when compared to the quantity at the end of the slow fermentation $(50.95 \mathrm{mg} / 100 \mathrm{~mL})$ and one month after the package $(34.01 \mathrm{mg} / 100 \mathrm{~mL})$. The same behavior was observed for the tannin content, decreasing from $108.63 \mathrm{mg} / 100 \mathrm{~mL}$ of the slow fermentation to $81.86 \mathrm{mg} / 100 \mathrm{~mL}$ with one month of packaging.

The variables that were influenced by the aging factor can be visualized in Figure $3(\mathrm{p}<0.05)$.
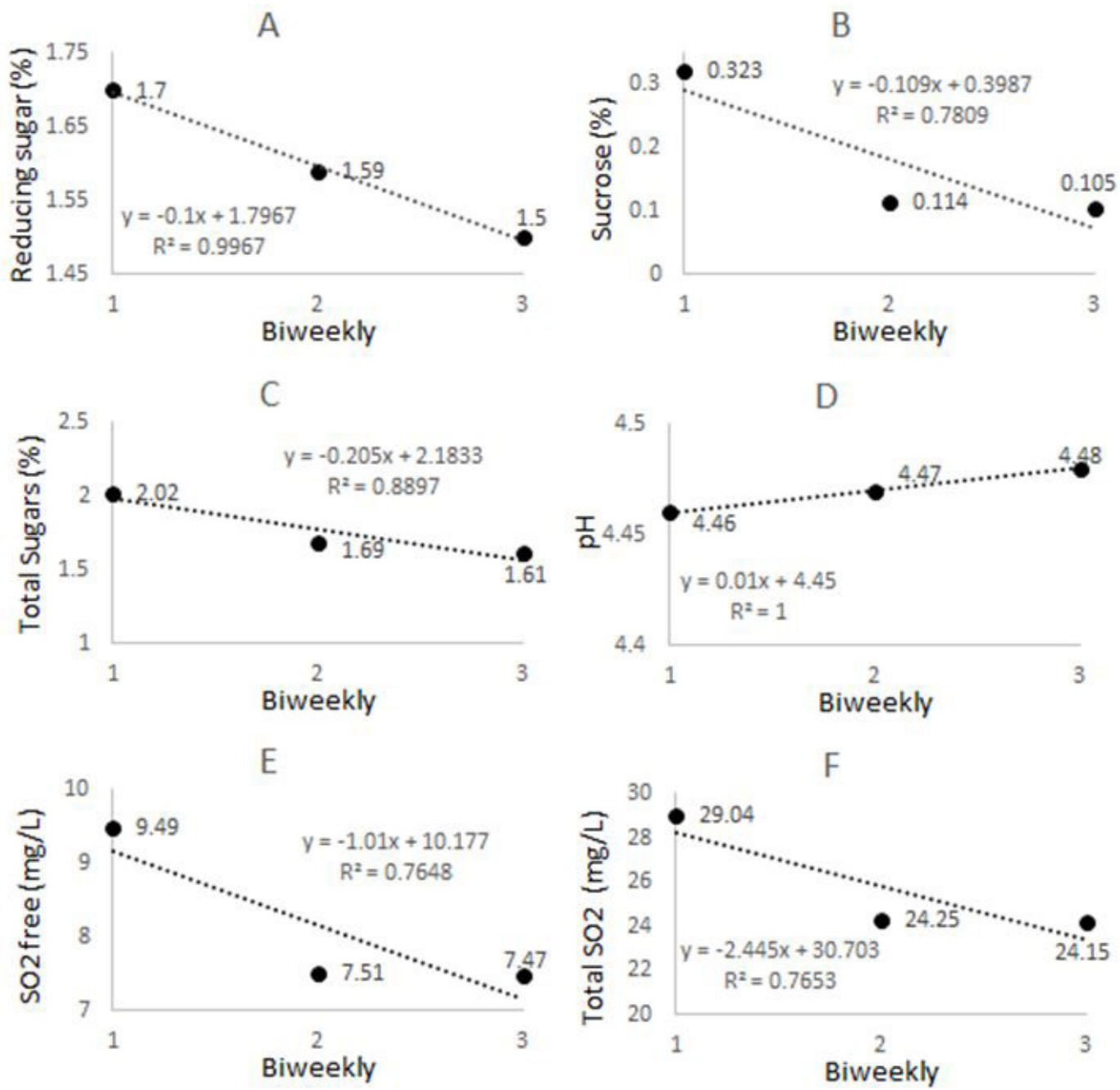

Figure 3. Behavior of the chemical characteristics of alcoholic fermentation of baru pulp (Dipteryx alata Vog.) During six months of aging. (A) Reducing sugars, (B) Sucrose, (C) Total sugars, (D) pH, (E) Free sulfur dioxide and (F) Total sulfur dioxide. S02 - Sulphurous anhydrous. 
The behavior of the sugars (reducers, sucrose and totals) during the aging process were decreasing and could be explained by reactions that may occur even inside the bottles due to the presence of a small quantity of yeast that may have remained, this decrease did not significantly affect the alcoholic content. In fermented jackfruit (Asquieri et al., 2008), a lower amount of reducing sugars was observed $(0.83 \%)$ and no values were detected for sucrose.

The $\mathrm{pH}$ of the jackfruit fermented (Asquieri et al., 2008) was lower (3.91) after 11 months of aging when compared to the present study. The behavior of the free and total sulfur dioxide compounds decreased over time, possibly because these compounds may have reacted with other factors within the bottles, mainly because of the presence of small amounts of oxygen. When compared to the literature, the baru pulp fermented had higher values than the fermented jackfruit (Asquieri et al., 2008), after 11 months of aging, obtaining $2.10 \mathrm{mg} / \mathrm{L}$ for free sulfur dioxide and $15.84 \mathrm{mg} / \mathrm{L}$ for total sulfur dioxide.

This difference occurred because, for the fermented of pulp baru, a greater number of sulphates were carried out during the elaboration process. The total sulfur dioxide content also fell within the scope of the legislation, which establishes a maximum of $0.35 \mathrm{~g} / \mathrm{L}$.

\section{Conclusion}

Throughout the processing, the fermented presented behavior as expected, as a decrease of sugars ensuring an effective fermentation without interferents, as high amounts of acetic acid and propagation of deteriorating organisms. With this, it was possible to develop and chemically accompany the alcoholic beverage from baru pulp, obtaining results that complied with the current legislation for fermented fruit, providing a new source of exploitation of this raw material little explored.

\section{Acknowledgements}

The authors thank the CAPES and CNPq for the financial support.

\section{References}

Almada, J. L. S., Dantas, D. L. L., Gaspareto, O., \& Filho, R. S. F. (2009). Elaboração e caracterização físico-química de fermentado alcoólico de abacaxi. In Anais do IV Congresso de Pesquisa e Inovação da Rede Norte e Nordeste de Educação Tecnológica. Natal: IFRN.

Alves, A. M., Mendonça, A. L., Caliari, M., \& Cardoso-Santiago, R. A. (2010). Avaliação Química e Física de Componentes do Baru (Dipteryx Alata Vog.) para Estudo da Vida de Prateleira. Pesquisa Agropecuária Tropical, 40(3), 266-273.

Amerine, M.A. \& Ough, C.S. (1976). Analisis de vinos y mostos. Zaragoza: Ed. Acribia.

Arruda, A. R., Cassimiro, A. R. S., Garruti, D. S., \& Abreu, F. A. P. (2007). Caracterização físico-química e avaliação sensorial de bebida fermentada alcoólica de banana. Ciência Agronômica, 38(4), 377-384.

Asquieri, E. R., Candido, M. A., Damiani, C., \& Assis, E. M. (2004a). Fabricación de vino Blanco y tinto de jabuticaba (Myrciaria jaboticaba Berg) utilizando la pulpa y la cáscara respectivamente. Alimentaria, 355, 97-109.
Asquieri, E. R., Damiani, C., Candido, M. A., \& Assis, E. M. (2004b). Vino de jabuticaba (Myrciaria cauliflora Berg): estúdio de las caracterísiticas físico-químicas y sensoriales de los vinos tintos seco $\mathrm{y}$ dulce, fabricados con la fruta integral. Alimentaria, 355, 111-121.

Asquieri, E. R., Rabêlo, A. M. S., \& Silva, A. G. M. (2008). Fermentado de jackfruit: estudo das características físico-químicas e sensoriais. Food Science and Technology (Campinas), 28(4), 881-887. http:// dx.doi.org/10.1590/S0101-20612008000400018.

Asquieri, E. R., Silva, A. G. M., \& Cândido, M. A. (2009). Aguardente de jabuticaba obtida da casca e borra da fabricação de fermentado de jabuticaba. Food Science and Technology (Campinas), 29(4), 896-904. http://dx.doi.org/10.1590/S0101-20612009000400030.

Association of Official Analytical Chemists - AOAC. (2010). Official methods of analysis (18th ed.). Gaithersburg: AOAC.

Bermúdez-Sotto, M. J., \& Tomás-Barberán, F. A. (2004). Evaluation of commercial red fruit juice concentrates as ingredients for antioxidant functional juices. European Food Research and Technology, 219(2), 133-141. http://dx.doi.org/10.1007/s00217-004-0940-3.

Bligh, E. G., \& Dyer, W. J. (1959). A rapid method of total lipid extraction and purification. Canadian Journal of Biochemistry and Physiology, 37(8), 911-917. http://dx.doi.org/10.1139/o59-099. PMid:13671378.

Boulton, R. B., Singleton, V. L., Bisson, L. F., \& Kunkee, R. E. (1995). Principales and practices of winemaking (The Chapman \& Hall Enology Library). Reino Unido: Chapman \& Hall.

Brasil. Ministério da Agricultura, Pecuária e Abastecimento. (1988). Portaria n 229 , de 25 de outubro de 1988. Complementação dos padrões de identidade e qualidade do vinho. Diário Oficial [da] República Federativa do Brasil.

Brasil. Ministério da Agricultura, Pecuária e Abastecimento. (2005, September 20). Aprova o Manual Operacional de Bebidas e Vinagres (Instrução normativa $\mathrm{n}^{\circ} 24$, de 08 de setembro de 2005). Diário Oficial [da] República Federativa do Brasil.

Carvalho, C. R., Mantovani, D. M. B., Carvalho, P. R. N., \& Moraes, R. M. M. (1990). Análises químicas de alimentos. Manual Técnico. Campinas: Instituto de Tecnologia de Alimentos.

Corazza, M. L., Rodrigues, D. G., \& Nozaki, J. (2001). Preparação e caracterização do vinho de laranja. Quimica Nova, 24(4), 449-452. http://dx.doi.org/10.1590/S0100-40422001000400004.

Curvelo-Garcia, A. S. (2005). Práticas enológicas internacionalmente reconhecidas. Ciência e Técnica Vitivinícola, 20(2), 105-130.

Daudt, C. E., \& Fogaça, A. O. (2008). Efeito do ácido tartárico nos valores de potássio, acidez titulável e $\mathrm{pH}$ durante a vinificação de uvas Cabernet Sauvignon. Ciência Rural, 38(8), 2345-2350. http:// dx.doi.org/10.1590/S0103-84782008000800039.

Dias, D. R., Schwan, R. F., \& Lima, L. C. O. (2003). Metodologia para Elaboração de Fermentado de Cajá (Spondias mombin L.). Food Science and Technology (Campinas), 23(3), 342-350. http://dx.doi. org/10.1590/S0101-20612003000300008.

Lima, J. C. R., De Freitas, J. B., Czeder, L. D. P., Fernandes, D. C., \& Naves, M. M. V. (2010). Qualidade microbiológica, aceitabilidade e valor nutricional de barras de cereais formuladas com polpa e amêndoa de baru. Boletim do Centro de Pesquisa e Processamento de Alimentos, 28(2), 331-343. http://dx.doi.org/10.5380/cep.v28i2.20450.

Merril, A. L., \& Watt, B. K. (1973). Energy value of foods: basis and derivation. Washington: Unites States Departament of Agriculture.

Miller, G. L. (1959). Use of dinitrosalicylic acid reagent for determination of reducing sugar. Analytical Chemistry, 31(3), 426-428. http://dx.doi. org/10.1021/ac60147a030.

Muniz, C. R., Borges, M. F., Abreu, F. A. P., Nassu, R. T., \& Freitas, C. A. S. B. (2002). Bebidas fermentadas a partir de frutos tropicais. 
Boletim do Centro de Pesquisa e Processamento de Alimentos, 20(2), 309-322. http://dx.doi.org/10.5380/cep.v20i2.1256.

Oliveira, L. A., Lordelo, F. D. S., Tavares, J. T. Q., \& Cazetta, M. L. (2012). Elaboração de bebida fermentada utilizando calda residual da desidratação osmótica de abacaxi. Revista Brasileira de Tecnologia Agroindustrial, 6, 702-712. http://dx.doi.org/10.3895/ S1981-36862012000100009.

Ough, C. S. (1996). Tratado básico de enologia. Acribia: Zaragoza.

Paula, B., Carvalho, C. D., Matta, V. M., Menezes, J. S., Lima, P. C., Pinto, C. O., \& Conceição, L. E. M. G. (2012). Produção e caracterização físico-química de fermentado de umbu. Ciência Rural, 42(9), 16881693. http://dx.doi.org/10.1590/S0103-84782012000900027.

Paz, M. F., Scartazzini, L. S., Ogliari, T. C., \& Burlin, C. (2007). Produção e caracterização do fermentado alcoólico de Actinidia deliciosa Variedade Bruno Produzido em Santa Catarina. In Anais do XVI Simpósio Nacional de Bioprocessos. Curitiba: UFPR.

Renard, C. M. G. C., Baron, A., Guyot, S., \& Drilleau, J. F. (2001). Interactions between apple cell walls and native apple polyphenols: quantification and some consequences. International Journal of Biological Macromolecules, 29(2), 115-125. http://dx.doi.org/10.1016/ S0141-8130(01)00155-6. PMid:11518583.

Ribeiro, A. E. C., Ascheri, D. P. R., \& Ascheri, J. L. R. (2011). Aplicação da metodologia de superfície de resposta para a seleção de uma bebida alcoólica fermentada de polpa de baru. Revista Agrotecnologia, 2(1), 57-72. http://dx.doi.org/10.12971/2179-5959.v02n01a05.

Rizzon, L. A., \& Miele, A. (2002). Avaliação da Cv. Cabernet Sauvignon para elaboração de vinho tinto. Food Science and Technology (Campinas), 22(2), 192-198. http://dx.doi.org/10.1590/S010120612002000200015.

Rocha, L. S., \& Santiago, R. A. C. (2009). Implicações nutricionais e sensoriais da polpa e casca de baru (Dipterix alata Vog.) na elaboração de pães. Food Science and Technology (Campinas), 29(4), 820-825. http://dx.doi.org/10.1590/S0101-20612009000400019.
Sano, M. S., Ribeiro, J. F., \& Brito, M. A. (2004). Baru: biologia e uso. Planaltina: Embrapa.

Sano, S. M., Vivaldi, L. J., \& Spehar, C. R. (1999). Diversidade morfológica de frutos e sementes de baru (Dipteryx alata Vog.). Pesquisa Agropecuária Brasileira, 34(14), 13-518. http://dx.doi.org/10.1590/ S0100-204X1999000400001.

Silva, P. H. A., Faria, F. C., Tonon, B., Mota, S. J. D., \& Pinto, V. T. (2008). Avaliação da composição química de fermentados alcoólicos de jabuticaba (myrciaria Jabuticaba). Quimica Nova, 31(3), 595-600. http://dx.doi.org/10.1590/S0100-40422008000300025.

Silva, R. N., Monteiro, V. N., Alcanfor, J. D. X., Assis, E. M., \& Asquieri, E. R. (2003). Comparação de métodos para a determinação de açúcares redutores e totais em mel. Food Science and Technology (Campinas), 23(3), 337-341. http://dx.doi.org/10.1590/S0101-20612003000300007.

Starzack, M., Krzystek, L., \& Nowicki, L. (1994). Macroapproach kinetics of ethanol fermentation by Saccharomyces cerevisiae: experimental studies and mathematical modelling. Chemical Engineering Journal, 54, 221-240.

Swain, T., \& Hillis, W. E. (1959). The phenolic constituents of prunus domestica. The quantitative analysis of phenolic constituents. Journal of the Science of Food and Agriculture, 10(1), 63-68. http://dx.doi. org/10.1002/jsfa.2740100110.

Togashi, M., \& Scarbieri, V. C. (1994). Caracterização química parcial do fruto do baru (Dipterix alata Vog.). Food Science and Technology (Campinas), 14(1), 85-95.

Torres, A. B. No., Silva, M. E., Silva, W. B., Swarnakar, R., \& Silva, F. L. H. (2006). Cinética e caracterização físico-química do fermentado do pseudofruto do caju (Anacardium occidentale L.). Quimica Nova, 29(3), 489-492. http://dx.doi.org/10.1590/S0100-40422006000300015.

Valillo, M. I., Tavares, M., \& Aued, S. (1990). Composição química de polpa e da semente do fruto de cumbaru (Dipteryx alata Vogel): caracterização do óleo da semente. Revista do Instituto Florestal, 2(2), 115-125.

Vogt, E. (1972). La fabricación de vinos. Zaragoza: Ed. Acribia. 